\title{
The Diary, the Typewriter and Representative Reality in the Genesis of Juha Mannerkorpi's Päivänsinet ${ }^{1}$
}

\section{Veijo Pulkkinen}

University of Helsinki

\section{ABSTRACT IN ENGLISH}

This article investigates the transition from keeping a diary to writing a future published work with reference to the genetic process of Päivänsinet: muuan loppukesän merkintöjä (1979) by Finnish author and translator Juha Mannerkorpi. The diary novel is about a seriously ill narrator who watches the growth of a morning glory, meticulously counting, measuring and registering the daily unravelling flowers with the help of a typewriter. In combining genetic criticism with Philippe Lejeune's ideas on the diary, antifiction and the diary effect, the article analyses the frequent metapoetic remarks upon the use of the typewriter and the relationship between fact and fiction in the context of the diary-writing process and its subsequent rewriting as a novel. Upon close inspection of the manuscripts it becomes clear that the typewriter was not a transparent medium that helped the weak-sighted author to write, but that the physical act of typing influenced the content of Mannerkorpi's text in many respects. In addition to shedding light on many experimental features of Mannerkorpi's works, this study on the genesis of Päivänsinet widens current understanding concerning the impact of writing tools on diary-keeping and literary writing.

Keywords: Juha Mannerkorpi, diary, genetic criticism, typewriter

\section{ABSTRAKTI SUOMEKSI}

Tämä artikkeli käsittelee siirtymää päiväkirjan pitämisestä tulevan julkaistavan teoksen kirjoittamiseen tarkastelemalla Juha Mannerkorven Päivänsinet: 
muuan loppukesän merkintöjä (1979) -teoksen syntyprosessia. Päiväkirjaromaani kertoo vakavasti sairaasta kertojasta, joka tunnollisesti seuraa päivänsinen kasvua laskien, mittaillen ja kirjoituskoneella ylöskirjaten sen päivittäin puhkeavia kukkia. Yhdistämällä geneettistä kritiikkiä Philippe Lejeunen ajatuksiin päiväkirjasta, antifiktiosta ja päiväkirjaefektistä artikkelissa analysoidaan Päivänsinissä toistuvia metapoeettisia huomioita kirjoituskoneen käytöstä ja faktan ja fiktion suhteesta päiväkirjan kirjoitusprosessin ja sen romaaniksi uudelleenkirjoittamisen kontekstissa. Yksityiskohtainen käsikirjoitusten tarkastelu tuo esille, ettei kirjoituskone ole läpinäkyvä väline, jonka avulla heikkonäköinen tekijä saattoi kirjoittaa, vaan että koneella kirjoittaminen fyysisenä toimintana vaikutti Mannerkorven tekstin sisältöön monin tavoin. Sen lisäksi, että artikkeli valottaa Mannerkorven teosten monia kokeellisia puolia Päivänsinien syntyprosessien tarkastelu lisää ymmärrystämme kirjoitusvälineiden vaikutuksesta päiväkirjan pitämiseen ja kirjalliseen työskentelyyn.

Asiasanat: Juha Mannerkorpi, päiväkirja, geneettinen kritiikki, kirjoituskone

Juha Mannerkorpi’s (1915-1980) last novel Päivänsinet: muuan loppukesän merkintöjä (1979, Morning glory: Entries from a late summer) was a huge critical success and it was awarded the Finnish Literature State Prize in 1980. It is a short novel, written in the form of a diary, about a seriously ill man who follows the growing and blooming of a flower called morning glory, or the Latin name ipomoea tricolor, and records his observations and thoughts on a typewriter. Päivänsinet is a stripped-down and very simplistic novel, unlike many of Mannerkorpi's earlier works that gave him a reputation as a challenging author (Lankinen 2001, 37). Notwithstanding the accessibility of Päivänsinet, the study of its genesis could also shed light on his more experimental works.

Mannerkorpi has been described as a lone wolf among post-war Finnish modernists, and because of his translations of Sartre, Camus and Malraux he was-and still is-repeatedly labelled as an existentialist (see, for example, Ervasti and Karkama 1973, 137; Kinnunen 1982; Pajukangas 2012, 72; Riikonen 2005), which he detested and renounced (1982b; Tikkanen 1972, 35; Lankinen 2001, 38-39; Mikkola 1982, 303). In fact, he was more favourable towards the Nouveau Roman movement, and parallels have been found between Mannerkorpi, Claude Simon and Alain Robbe-Grillet in the detailed depiction of things and the use of repetition, for example (Tikkanen 1972, 122-123; Helme 1995, 6, 25, 53). If there ever was a writer Mannerkorpi felt affinity with it was Samuel Beckett: he translated three of Beckett's works from French and also visited him in Paris in December 1963 (Mannerkorpi 1962; 1966; Anonymous 1963). 
Many of Mannerkorpi's works have autobiographical elements (Kinnunen 1976, 25), but they are perhaps most obvious in Päivänsinet, which is based on a diary that he kept from 2 July 1978 to 10 February 1979 .

The genetic dossier of Päivänsinet contains four manuscript versions (Table 1). The diary and the manuscripts are deposited in the Literature and Cultural History Collection of the Archive of the Finnish Literature Society in Helsinki (= SKS KIA). The first manuscript is the original diary, the second is a rewritten version of the diary text, the third is a revised version of the rewritten diary text and the fourth is a fair copy that was used in the type-setting of the published text. This was typed using a different typewriter-and judging by its professional appearance, probably not by Mannerkorpi-so it is very likely a copyist's typescript.

In my investigation of the genesis of Päivänsinet, I will focus mainly on the original diary and the manuscript containing the rewritten diary text, because the most notable changes to the text are evident in these two documents. The diary has 104 text pages and 145 dated entries, whereas the rewritten diary text has only 107 entries on 86 text pages. The number of entries is the same in the later manuscripts as well as in the published text. The explanation for the fall-off in entries is that Mannerkorpi deleted and combined entries as he rewrote the diary. The genesis of Päivänsinet thus raises the question of the relationship between the diary and the fictional account.

The typewriter had a central role in the writing process, as well as in the content level of Päivänsinet: Mannerkorpi typed both his diary and all the manuscripts of the published work (there are additions and corrections made with a pen, especially in the rewritten diary text and the revised manuscript). Moreover, both Mannerkorpi and the narrator of the novel make frequent metapoetic remarks about the relationship between fact and fiction and the use of the typewriter. On one occasion (RDT, 39) the typewriter is called a "machine that produces

Table 1. The Genetic Dossier of Juha Mannerkorpi's Päivänsinet

\begin{tabular}{lll}
\hline Document type & $\begin{array}{l}\text { Number of } \\
\text { text pages }\end{array}$ & $\begin{array}{l}\text { Number of } \\
\text { entries }\end{array}$ \\
\hline The original diary (= OD) & 104 & 145 \\
The rewritten diary text (= RDT) & 86 & 107 \\
The revised manuscript (= RM) & 93 & 107 \\
Corrected copyist's manuscript & 92 & 107 \\
\hline
\end{tabular}


representative reality' [esittävän todellisuuden tuottolaite], which connects it with the theme 'representative reality' that occurs frequently in Mannerkorpi's oeuvre. In a nutshell, representative reality is about the problem of representation, in other words the gap between perceivable reality and language.

In what follows I begin by investigating the transition from keeping a diary to writing a future work, making use of Philippe Lejeune's ideas on the diary, genetic criticism and antifiction. First, I trace the moment and textual location at which the keeping of the diary turns to the writing of an avant-texte of a future work, and then I show how this turn overlaps with the change from antifiction to fiction. The rest of the article is dedicated to the theme of representative reality. I argue that not only is the concept relevant to the content level of Mannerkorpi's work, it is also applicable to his writing process and the use of the typewriter. In my analyses of the diary and the manuscripts of Päiväsinet I will show that the typewriter is not a neutral writing tool, and that the physical act of typing could have significantly influenced the content level of Mannerkorpi's text, for instance, in the form of random typos and other whims of the writing process that often became the subject of his text.

\section{FROM DIARY TO AVANT-TEXTE}

According to Lejeune, a diary is an exceptional research object for genetic criticism in that it does not have an avant-texte (Lejeune 2009, 223). There is no single, commonly agreed upon definition of the concept of the avant-texte, but I do not think it is totally wrong to say that it refers to the genetic process of a literary work and its surviving material documents, such as notes, sketches, drafts and working manuscripts (compare Biasi 1996, 38). ${ }^{2}$ The avant-texte could thus be considered the research object of genetic criticism, which one can investigate by studying manuscripts and other material that shed light on the writing process.

According to Lejeune, a diary cannot have an avant-texte because it is written one day at a time. Although an entry is not usually written out fully at the first attempt but develops throughout the day as the writer plans the text mentally, for example, there is no access to these preliminary processes. Diaries certainly have features that are typical of all manuscripts such as crossings-out, additions and extracted pages, but basically the idea and the logic is that a diary entry is written when it is dated (Lejeune 2009, 223-226). 
Although a diary does not have an avant-texte, it can become one. This happens when the opportunity to publish it arises: it becomes a draft that has to be finished and edited in order to be publishable (Lejeune 2009, 226-227). Mannerkorpi's diary is interesting in this respect in that the idea of turning it into a published work arose at the time he was writing it, not after the diary was finished. This change from diary to avant-texte can be dated and pointed out quite accurately: it happens on 9 August at ten minutes to two in the afternoon, on page 33. It is in this entry, which he omitted from the later versions, that Mannerkorpi first explicitly mentions that he is considering writing a publishable work based on it:

Phew. Finally here. I jointed the chicken and put it in a pot with all the ingredients and turned on the oven. If it turns out to be especially good, heh heh, I'll write the recipe here, it is my own brainchild.

Finally here? For that, for a promise of a splendid chicken recipe. Who the hell knows? But in some fundamental way I am rushing to this place morning after morning. Or better, afternoon after afternoon, since I have learnt from sitting and nodding that it is not worth trying to defeat it by force. But that pressure to come here and a slight pull at the same time? Might one conclude that there is a hidden theme worth realizing in what I have been writing for two months now? An old man, with a cancer sentence, counting his days. And rejoicing every time a new one dawns. When old men and ladies tend the flowers in their window boxes, they presumably tend the symbols of their own continuance, as well as much else, of course. But you don't need to know that if you write a short story, for example. You'd think that the piece would work solely on the grounds that there are some basic human needs fulfilled in tending and watching a growing thing. Too bad that the theme requires some sort of naivety, and I am not complete enough for such expression. ${ }^{3}$

In the case of an established author such as Mannerkorpi it is, of course, not easy to make a clear distinction between 'pure' diary keeping and the writing of an avant-texte for a possible future work. Mannerkorpi used similar methods to produce textual material for his earlier work, especially in his essay Kolme vuosikymmentä sokeritautia (1972, Three decades of sugar disease), which is in part a medical report and in part an intellectual autobiography, written in the form of seven diary entries dated between 15 and 21 March 1972. About a third of the text of the novel Jälkikuva (1965, After-image) consists of dated passages, which indicates that they were originally composed as a diary. In Matkalippuja kaikkiin juniin (1967, Tickets to all trains) Mannerkorpi experimented with some sort of surrealist automatism, writing down his dreams immediately when he woke up and was still half asleep so the text assumed the 'lines and the very syntax' [viivat ja oman syntaksin] of the dream (Tikkanen 1972, 
345). These dream passages were printed in the novel almost as such, without uppercase letters and punctuation, regardless of conventional syntax and structure (for example, Mannerkorpi 1967, 11-12). Mannerkorpi also records a few dreams in Päivänsinet, but they are written in more conventional language.

Although an author's diary is more likely to become an avant-texte, it does not make this turning point in Mannerkorpi's case any less significant. It is the temporal and spatial point at which the possibility of becoming an avant-texte is realised. After keeping the diary for a month, Mannerkorpi recognizes a theme that he explicitly begins to pursue. From here on he perceives of himself and his actions in more symbolic and thematic terms, which also affects the way he keeps track of the growing morning glory, his sickness and his writing. The goal is not to publish the diary as it is but to use it as material for a literary work, such as a short story. Here, the temporal character of the diary text is doubled when it becomes an avant-texte. As a diary, the entries are ready at the moment they are written down. But from the avant-texte perspective, the entries are initial drafts of a writing project, that is, a process of becoming a text (compare Lejeune 2009, 225). It is debatable, whether a text can really be finished. According to Pierre Marc de Biasi, the border between the avant-texte and the text is defined by the bon à tirer (pass for press), that is, when the author gives the permission to print the text (Biasi 1996, 33, 36). But as Dirk van Hulle has pointed out, in addition to a genesis, a work may also have an epigenesis when the author have continued to revise the text after its publication (Hulle 2014, 213-214; 2018, 47).

The change from diary to avant-texte marks the transition from antifiction to fiction. Using the term antifiction, Lejeune defines the diary as a genre. The term is in deliberate opposition to fiction, which is fabrication by definition, and in this way Lejeune underlines the relation that the diary has to truth and reality (Lejeune 2009, 203). He describes the diary novel as a hybrid genre that combines two contrary genres: it is fiction that pretends to be a diary by imitating features that are typical of diaries, but only to the extent that it differs from other types of fiction. Real diaries tend to be too long, too repetitive, too incoherent, too meaningless and too implicit, in other words the entries do not necessarily make sense to outsiders. Such features are typical of diaries, but at the same time they are features that make a text unpublishable (Lejeune 2009, 207).

The most significant difference between a diary and a fictive work is in the ending. According to Lejeune, unlike fictive works a diary is not written with the end in view. Diaries are open-ended, and as such they protect the writer from the idea of the end and of death, always promising 
a new day and a new entry to be written (Lejeune 2009, 188-189, 197). In this respect, Mannerkorpi's diary is perhaps best understood as one of those exceptional cases in which a diary has a predestined ending. In following the lifespan of the morning glory, which is an annual plant, Mannerkorpi's diary is temporally limited and thematic, like a travel journal or pregnancy diary (Lejeune 2009, 189). However, it is also the diary of a seriously ill person. Mannerkorpi suffered from diabetes for almost forty years. In his $60^{\text {th }}$ anniversary interview, Mannerkorpi lamented that he was too weak to write anymore (Saviniemi 2010,35). However, after an almost ten-year hiatus, Mannerkorpi started to write his diary. He had been diagnosed with cancer but he refused surgery. It was not certain that Mannerkorpi would outlive the morning glory. In that respect, his diary-keeping might have had what Pawel Rodak calls an autotherapeutic function. Keeping a diary could, for example, help to maintain a life balance in a situation of suffering and depression, as well as being a personal ritual through which to banish bad thoughts and emotions (Rodak 2018, 165). In Mannerkorpi's case, it was writing in the face of death and an unknown future, which is also presented in the above entry. The morning glory produces new flowers every morning, which droop and wither as the day progresses. For Mannerkorpi, every day was thus a promise of a new blossom as well as a new diary entry. Both were symbols of continuity.

Mannerkorpi died in 15 September 1980, just about a year after the publication of Päivänsinet.

\section{FROM ANTIFICTION TO FICTION}

As such, a fictional text passage does not turn a diary into fiction. Diaries often contain made up stories, fairytales, prose, aphorisms, philosophical or religious meditations, etcetera. For Lejeune, the point between the distinction between antifiction and fiction is that a fictive diary pretends to be written in the present, in a certain date, which, of course, is a lie (2009, 202). A real diary entry, on the contrary, is always written at a particular date regardless of its content, be it fictive or not.

It is, however, interesting that Mannerkorpi's diary begins to show signs of fiction when it turns to an avant-texte. This can be understood just as a way to make the text more literary, but it can also be interpreted as a change in the aim of his writing. The text is not just a diary but also the first draft of a possible future literary work. This is particularly apparent in the urge to create a mythical level in the text. In the entry he made on 7 September 1978 , for instance, he counts the buds on the morning glory as usual but 
also expresses his wish to find literary sources on the flower. In other words, he wants to create intertextual links to a possible literary tradition.

I would like to get an inkling of the literature on this ipomoea, which would give information about possible spells, habits and beliefs related to it. There must be some. If I were respected and wealthy, and healthy as well, I would go to Central America and ask the Native Americans about it. But no. I have to content myself with consulting head gardeners and professors of plant sciences. At least they give me a bit more botanical knowledge than the encyclopaedia does. I already tried yesterday, and this is what I found out. The original name Ipomoea violaceae, then Ipomoea tricolor given by Linné, and then a third one, Ipomoea rubrocoerulea, which I think is the most fitting. The names come from English and were translated into Finnish by Puupponen, the Head Gardener of the Botanical Garden of the University of Turku, a horrible number of genitives, in his KORISTEKASVIT [Flowering Plants]. I hear it has a colour illustration although the picture of the ipomoea is bad. The leaves are described as heart-shaped, pointed. I don't think this domestic god of ours is a fit model for a heart-like form. ${ }^{4}$

Mannerkorpi telephoned Puupponen to ask about literature on the morning glory, but to no avail (OD 11 September 1978, 64). After about a month he asked Pentti Alanko, the Head Gardener of the botanical garden of the University of Helsinki, the same question. Alanko promised to find out, but he knew straight away that the plant contained narcotic qualities, which gave Mannerkorpi hope. 'Jos se moinen ihmekasvi on, luulisi siitä sitten liikkuvan jos mitä tarinoita ja legendoja maissa missä se elää ja vaikuttaa.' [If it is such a wonder plant, one would think that there are all sorts of stories and legends about it in the countries where it exists and grows.] (OD 4 October 1978, 79).

Ten days later and still there was no news about any literature on the plant. Mannerkorpi wrote on 14 October 1978 that he had phoned an artist who had lived among the Incas in Equador, asking about the legends, spells and uses of the morning glory, but again without result. He therefore decided to create his own mythical genesis for the flower:

I suppose I have to cast my own spells and make up my own fairy tales.

Like this one, for example:

The Great Spirit had created the heaven and the earth and everything in between. Only the stars were missing. He had not invented them yet. And it came to pass that on a certain night he went down to Earth to see the work of his hands, and lo and behold, it was good. But it happened to be a moonless period and rather dark. Thus, the Great Spirit took a scallop from the seashore and used it to cut holes into the surface of the sky. The Great Spirit 
cut the surface of the sky full of holes, and lo and behold, now the mountains and hills and lakes and men through forests and tree lines were clearly visible and the Great Spirit rejoiced as he wandered in the light of the stars.

And when the Great Spirit cut holes in the surface of the sky, the pieces fell to the earth, and when morning came, lo and behold, large round blue pieces of the surface of the sky were on the trees and bushes, and large blue flowers blossomed everywhere.

$\mathrm{Hmm} .^{5}$

The fairy tale of the morning glory is the culmination of Päivänsinet when the daily routine of struggling with the afflictions of the diseaseridden body and counting, measuring and recording the blooms suddenly assumes a mythical, symbolic and thematic aura. It is easy to draw a parallel between the birth of the flower and the process of writing Päivänsinet. The diary does not have an avant-texte, in other words there is no textual material documenting its genesis. However, it could become an avanttexte of a published version of itself in the same fashion as Mannerkorpi invented a fairy tale about the birth of the morning glory. In both cases it happens with the help of fiction. Mannerkorpi fills the gap of the flower myth with a fabrication, and in the case of the diary the logic of writing switches from antifiction to fiction, from private entries to the writing of a publishable work. The comparison between the two is also supported in the detail: the morning glory is the by-product of the birth of stars, in other words bringing light into the dark night. It carries the traces of a genesis, like manuscripts that bear witness to the writing process of a work.

Mannerkorpi placed the fairy tale of the morning glory almost at the end of the published work. There are only eleven entries after it, whereas there are fifty-one in the diary, most of which only follow the gradual withering of the flower. On 28 October 1978, that is two weeks after writing the fairy tale, Mannerkorpi questioned the continuation of the diary in an entry that he deleted from the later manuscript versions:

Should one continue to keep this thing called a diary in this fashion, by the way? It feels as if the theme is about to be drained. When I started in July it felt like I had inflicted violence on something that exists, begun to transfer it to the world of written language. But this Morning Glory did not pale by any means. Words pale and grow weary, until they end. The perceptible reality of the Morning Glory has lost nothing.

And I have seeds-for so many years until something else happens. This was the best summer in ages.

And I won't end this Morning Glory book here, either. ${ }^{6}$

It is worth noting that the motive behind ending the diary was not the ending of the lifespan of the flower, which would be in line with the 
concept of the predetermined ending of a thematic diary. The reason for ending it was rather the exhaustion of the thematic content of the entries. In other words, the diary no longer functioned as the avant-texte of a coming work. One might perhaps even say that from here on Mannerkorpi was again writing a diary rather than an avant-texte in that he would not stop writing entries, and he had seeds for new flowers.

He nevertheless continued to write the diary only as long as the morning glory showed signs of life. The last entries were written post scriptum on 10 January and 10 February 1979 . When he rewrote the diary text for the novel he condensed and polished the ending into a readable whole by deleting the above entry pondering on the ending of the diary, for instance, and making additions that strengthened the thematics of the work.

\section{REPRESENTATIVE REALITY}

Mannerkorpi also brings up the violence of writing in the entry about the ending of the diary. He seriously doubts that language can represent perceptible reality. It is suggested in previous research that this so-called theme of 'representative reality' [esittävä todellisuus] recurs throughout Mannerkorpi's oeuvre (Kinnunen 1976, 34-35, 48-49; Lankinen 2001, 37; 2002, 482; Makkonen 1986, 78-79 endnote 2; Kokko 2009, 137, 148; Mäkelä 1983, 128-129; Poso 1987, 206-209; Salin 1998, 66-69). Anna Kuismin (formerly Anna Makkonen) points out that the word 'esittävä' means more in Finnish than just 'representational': 'the verb esittää is to show, to perform, to present, to represent' (Makkonen 1986b, 38). To this one could add meanings such as to produce; to express, to state, to set forth, to propound; to propose, to suggest, to put forward; to offer (an invitation, for instance); to act, to deliver; to play, to pose, to pretend, to impersonate; to render, to portray, to depict, and to symbolize (compare Uusi Suomi-Englanti Suursanakirja).

Representative reality is first mentioned in the monologue Avain: Luulevaisen sydämen yksinpuhelu (1955, The key: Monologue of a distrustful heart), but according to Mannerkorpi, the thinking behind the concept has a longer history (Tikkanen 1972, 165-166). ${ }^{7}$ The question of reality and the possibility of saying something about it had interested him ever since he started to write seriously. After finishing his Master's degree in 1945 he decided to focus on writing instead of pursuing a career as a psychologist, motivated by the intuition that he could get closer to truth and reality by literary means than by doing research (Tikkanen 1972, 96). 
What fascinated him the most was the human capability to think, dream, imagine and fictionalize.

What makes him a man, he is a man precisely because of this, that he has this symbolic function/representative reality and all, all his knowledge and so on, everything that is involved in it, that represents something, that as a mental event is a fact, for instance dreaming and thinking, which is a fact as an event, but it represents something else that is entirely somewhere else. This is exactly what makes a human being a human being, and as the phrase goes 'separates him from animals'.

Mannerkorpi treats the theme of representative reality in his works on several different levels, of which the relation between language and reality is a central one. It appears not only in several musings on the relation between the meaning of words and their referents, but also in the setting of some of his works, such as the monologue Avain in which the soliloquist is unable to exit his apartment and instead imagines himself at a birthday party with guests; or the protagonist of the novel Sudenkorento: erään Pakaraisen esittävät seikkailut (1970, The dragonfly: Or the representative adventures of a certain Buttocks), who is unable to go for a walk in the forest nearby and instead imagines himself on an adventure. ${ }^{9}$ While it is possible to create a fictive parallel reality with language, it is considered undesirable. Representative reality is not real: it is rather negative, especially on the ethical level, in relation to other people. One just pretends, without any real intimacy. One speaks without real mutual understanding (Kinnunen 1976, 35; Makkonen 1986b, 78-79).

The theme of representative reality is connected to writing and to the use of the typewriter in Mannerkorpi's diary and in Päivänsinet. ${ }^{10}$ As in the chicken recipe diary entry above (OD, 33), it is to the typewriter that Mannerkorpi returns every afternoon to record the events of the day. It is the tool with which he produces representative reality on the basis of perceivable reality. The typewriter is not a neutral, transparent medium, however: its own materiality defines the act of writing, at times so significantly that it becomes the subject of the text.

Friedrich Nietzsche famously remarked that our writing tools collaborate with our thoughts (Nietzsche 1981, 1: 202). At the time Nietzsche's eyesight was deteriorating and he tried out the skrivekugle [writing ball] invented by Rasmus Malling-Hansen, which was the first commercially produced typewriter. However, the typewriter was defective and Nietzsche never learned to use it properly. He only typed about fifty-seven typescripts including letters, a postcard and some verses (Eberwein 2005, 51). Nevertheless, Friedrich Kittler thinks that the typewriter profoundly 
changed his style 'from arguments to aphorisms, from thoughts to puns, from rhetoric to telegram style', and he argues that it was precisely this change that Nietzsche referred to with his remark on the relationship between our thoughts and writing tools (Kittler 1999, 203).

By investigating the typescripts of Mannerkorpi, who also had problems with his eyesight, we can see how the use of the typewriter directly influences his thinking and writing. This happens already at the beginning of the diary, at the end of the second entry, dated 3 July 1978. Mannerkorpi alludes to the typewriter only indirectly with reference to the physiological side effects of its usage: 'Kynsi murtui. En ole kirjoittanut aikoihin, ja nyt kahden liuskan täytyttyä kynsi murtunut1' [A nail has broken. I haven't written in a while, and now after filling two pages a nail has broken1] $(\mathrm{OD}, 3)$. It is, of course, obvious that the diary was typewritten when one reads the typescripts. However, it is less clear when one reads the printed book, although it can be deduced from the content (I imagine that it is rather rare to break a nail while writing with a pen). The working manuscript of Päivänsinet is more explicit on the use of the typewriter: 'Kynsi murtui. En ole painellut kirjoituskoneen näppäimiä vuosikausiin, ja nyt, pari liuskaa ja kynnet hajalla.' [A nail broke. I haven't pressed the keys of the typewriter for ages, and now, a few pages and nails are breaking.] (RDT 4 July 1978, 4).

There has been a lot of discussion about materiality in literary studies over the past few years. However, it is mostly understood metaphorically, as the aural or visual dimension of texts, for example. In the case of Mannerkorpi's diary one can refer to materiality in a somewhat tangible sense. The very sound of the mechanical typewriter was enough for the apparently tender-eared Mannerkorpi, which is shown in the entry from 13 July:

Cotton wool into ears, cotton wool into ears. Immediately when I hear the rattle of the typewriter like now, I realize that I have forgotten the cotton wool: it is as if the keys are tapping directly onto the eardrum.

Well, the cotton wool is in place. The tapping is still audible, of course, but it does not feel like it is touching me. ${ }^{11}$

It is worth noting that the sound was not only loud, it also felt as if it was touching the eardrums. When Mannerkorpi rewrote the diary text he emphasized this sense impression even more. The typewriter became a rock crusher, and it felt as if nails were being hammered through the eardrums (RDT, 13 July 1978, 15. Compare RMT, 13 July 1978, 14-15 and Mannerkorpi 1979, 23). Thus, it was not only a device for recording perceptible reality, it also rather violently created perceived reality. 
The loudness of the typewriter interrupts the writing process and forces the writer to get some cotton wool. The interruption is transferred to the visual layout of the text as a new paragraph and indentation. In this way, the physical experience of typing and the actions involved in it can directly influence the content and the appearance of the diary entry.

This is not a one-off phenomenon in Mannerkorpi, and it also appears in his other works. In fact, there is an almost identical scene in Sudenkorento, in which it seems as if eardrums were the ribbon and the brains were the typewriter platen (Mannerkorpi 1970, 35). The novel also has a chapter called 'Muurahaiset' [The ants], which is almost entirely about installing a typewriter ribbon. With all the cursing it resembles the diary entry written on 10 July.

Cries of damn, hell, bugger and god damnit ahead: I'm trying to install a darker ribbon into this representative reality-producing machine.

Twenty minutes later.

A few of those cries for help were needed, but surprisingly only a few. And I am not soaking wet. Damn it, there should be some sort of cartridge to install the ribbon for the visually impaired, the more impaired, the more automatic.

But the print seems to be pretty black. I can see with my distance glasses as I'm supposed to: I don't have to change to reading glasses for every glance. ${ }^{12}$

The transition from perceivable reality to representative reality is quite tangible when the original text passage in the diary is compared to the later versions (Figure 1). There are clear traces of the installation of the typewriter ribbon on the diary page: the imprint changes from light to dark and the text lines at the beginning and the end of the page are not in line, which indicates that the paper was removed from the typewriter and re-inserted during the operation. There are no such traces in the manuscripts of the rewritten diary text, let alone in the published text of Päivänsinet. The diary and the later versions have different referents in this text passage: the diary text refers to its own physical imprint (that is, perceivable reality) whereas the later versions are fiction (that is, representative reality) in that they only pretend to refer to their own materiality.

Borrowing Roland Barthes's concept of the reality effect ('effet de réel'), Lejeune terms this kind of fictional imitation the diary effect ('effet de journal'). Barthes' reality effect alludes to the small details in a story that are supposed to give a sense of reality (Barthes 1968, 88; Lejeune 2009, 207), whereas in Mannerkorpi's terminology, the referent of the diary is perceivable reality whereas in the later versions it is representative reality. Transition from perceivable reality to representative 
somaan, e1 ollut.

B1pl p1tänyt paikikaan. Juur1 Marjatta tåni aamuna tuli sancoaran :

- Siellihtin on kolme.

10. 7 .

Tanalin yks1.

Pirut perkeleet saatanat jumelautat edesali: yrittin

calihtas tiihain esittivàn todelissuden tuottovilineeseen musteman nawhan.

Kaksikgmenta minuuttia myơmenmin.

Mutamia yluanainiyyuja avunikutoja tarvittiln, him-

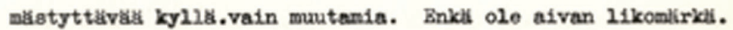
P1ru olkoon, alikővamaisille pitilsi newhanva1htotarko1 tukseen olla jokin kasett1laite, sita automaarriseapi mitk vammafsemmasta on kysymys.

Kutta ajka muataa täma jalki najttka olevan. Naen intturo1llani kuten oll tarko1tuakin: el tarvitae joka tionystyetic varten vaintas kantturoinin.

11. 7 .

Ja1leen yksi. T1esin missa kohden se on, Karjatta nkytt1 11lalla:kbrikealla, ylanaruisas. Kutta en het1 armulla jaksanut kliyda katsomasa, pelktain ettk vilkaisukin y26splin heittai minut selulleni. Vasta puoleltapisinin kaivin juotua kun jail jo tuntui pysyvăn pystyssă, menin katsomasn. Ja silnkihain se

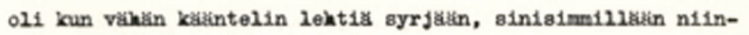
kuin se puolipaivăn alkaan on, värielávyngă noutaneens minun valtavasta nuorukalailin uneatani.

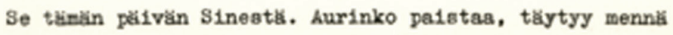

Figure 1. Page 11 from Juha Mannerkorpi's diary. Helsinki, Archives of the Finnish Literature Society, SKS (scan SKS). 
reality in this text passage thus overlaps with the change from antifiction to fiction.

Barthes underlines the uselessness and meaningless of the reality effect in the structure of a realistic narrative. Trivial details have no function that supports the narration or content, and rather seem to be totally random (Barthes 1968, 85). In the case of Päivänsinet, however, a random detail may become significant when it is turned into fiction, as in the diary entry written on 4 August in which Mannerkorpi refers to intentionally and unintentionally misspelled words. An accidentally typed extra full stop catches his attention and results in a comment, and eventually causes Mannerkorpi to forget what he was writing about.

\begin{abstract}
And there are Five Glories today. Let it be noted that I am spelling Glory and Five with an initial uppercase letter intentionally, because my writing technique has turned very modern: it is suspiciously starting to resemble computer typesetting: mistakes mistakes mistakes, misspellings, incomplete sentences, words collapsed into incomprehension. As if I had tried to go for a stroll with my club foot.. What is that, one extra full stop at the end of the sentence. When one constantly staggers and slips, whatever one does, yes yes, I don't recall what I was about to say. ${ }^{13}$
\end{abstract}

Mannerkorpi turns the random extra full stop into two extra full stops in the rewrite of the diary text, and adds an initial short comment on it followed by a slightly longer hand-written comment in the margin (the hand-written additions and corrections are in italics).

\footnotetext{
Evening stroll of a club foot... What is that, two extra full stops at the end of the sentence, well, let them be, they may represent whatever they do. They ended there when I sat for half an hour, palm on cheek after I struck one and I did not check whether I had struck one, then after another half hour the other palm on cheek and lo and behold, when I finally checked, there were three full stops. When one constantly sataggers and slips, whatever one does, yes yes, I don't recall what I was about to say. ${ }^{14}$
}

Here again the diary and the later versions have different referents. The entry in the diary refers to the very act of writing and the real misspelling within it, whereas in later versions it is fiction: it only pretends to be a misspelling. It does not even imitate the original typo but turns it into two extra full stops that are not at all random and meaningless like a single extra full stop. A series of three dots, of course, symbolizes an ellipsis, which is open to all sorts of interpretations (see, for example, Chamarette 2007; Hawthron 2011). Mannerkorpi notes this himself in the added comment: 'may them represent whatever they do'. 
Reality effects also emerge at the stage when Mannerkorpi rewrites the diary. For instance, editing the entry from 21 August he adds a reference to the writing process, not the process of writing the diary, but rather its rewriting (compare OD, 44-45). The previous entry in the rewritten diary text ends with the letters 'Hmm', which catches Mannerkorpi's attention.

Aha, I sat down here, I saw the last word of yesterday's entry, hmm. Well, if it is a word. But it is fit for the basis of a dream. I'm browsing the papers, these morning glory sheets, a thes pile, I browse, the pile grows thicker and I notice: apparently, I have written 'hmm' too many times. ${ }^{15}$

Another interesting thing is that, instead of deleting a repetitive expression that is unfit for publication but quite common in diaries, Mannerkorpi inserts it into the work as a reality effect, although it was not in the original diary.

As Aarne Kinnunen observed, typos are included in the metalanguage of Mannerkorpi's novel Sudenkorento. Here this implies suspicion of the language's ability to represent reality because typos often turn out to make sense (Kinnunen 1976, 31-32). Thus, it seems that writing is able to produce meaning independently of its user. Similar phenomena are present in Mannerkorpi's other works such as Matkalippuja kaikkiin juniin, in which the protagonist has a typewriter with a flawed letter 'J', which prints a letter that looks more like 'U'. For example, when he types 'JUNIIN' [to trains] it turns to 'UUNIIN' [into the oven] (Mannerkorpi 1967, 19).

Studying the transition from Mannerkorpi's diary to Päivänsinet from the perspective of genetic criticism and taking the use of the typewriter into account reveals new sides of Mannerkorpi's writing and of his published works. The manuscripts shed light on the many experimental features of his texts and the frequent metapoetic comments on writing. In particular, they give the impression that typos and other similar whims in the writing process relate not only to the theme of representative reality but perhaps also to some sort of poetics of randomness. According to Kittler, the typewriter broke the 'media-technological basis of classical authorship', which rested on the conscious cooperation between the eye and the writing hand as it enabled one to type without having to look at the text. Kittler relates this 'blindness' of mechanical writing with the unconscious, which was especially embraced by surrealists such as André Breton (Kittler 1990, 195; 1999, 202-04; see also Schilleman 2013, 17-7). As a representative realityproducing machine, the typewriter played a central role in Mannerkorpi's writing process as well as in his poetics. It made it possible for the 
weak-sighted author to write, but the material features of typing also caught his attention insomuch as they could change the direction of his text and even interrupt the writing process. However, unlike many other writers, he seemed to listen to what the typewriter had to say. He had an ear for randomness or the unconscious: for the meanings that language can produce together with the writing tool regardless of its author's will. These random whims of the writing process that turn into textual content are like traces of sensory reality or cuts in the surface of representative reality.

\section{BIBLIOGRAPHY}

\section{Archival sources}

Mannerkorpi, Juha. Päivänsinet. Muuan loppukesä, merkintöjä. The diary and the manuscripts of the novel. Juha Mannerkorpi's archive. Box 2-3. Archives of the Finnish Literature Society, SKS KIA, Helsinki.

Mannerkorpi, Juha. 'Kolme vuosikymmentä sokeritautia.' Manuscript. Juha Mannerkorven arkisto. Box 3. Archives of the Finnish Literature Society, SKS KIA, Helsinki.

Tikkanen, Aino-Maija. 'Juha Mannerkorven kirjailijahaastattelu.' [1972]. Transcription by Raija Pakkanen (1989). AB2383. Kl. 18694. Juha Mannerkorpi's archive. Archives of the Finnish Literature Society, SKS KIA, Helsinki.

\section{Other sources}

Anonymous. 'Kirjailija Juha Mannerkorven haastattelu.' [27.5.1963]. YLE Elävä arkisto. https://yle.fi/aihe/artikkeli/2006/09/08/juha-mannerkorven-eksistentialismi. Date accessed: 5 August 2019.

Barthes, Roland. 'L'Effet de Réel.' Communications 11 (1968) 84-89. https://www.persee.fr/ doc/comm_0588-8018_1968_num_11_1_1158. Date accessed: 5 August 2019.

Biasi, Pierre-Marc de. 'What is a Literary Draft? Toward a Functional Typology of Genetic Documentation.' Trans. Ingrid Wassenaar. Yale French Studies 89 (1996) 26-58. http://www.jstor.org/stable/2930337. Date accessed: 5 August 2019.

Chamarette, Jenny. 'Flesh, Folds and Texturally: Thinking Visual Ellipsis via Merleau-Ponty, Hélène Cixous and Robert Frank.' Paragraph 30:2 (2007) 34-49. http://www.jstor.org/ stable/43152587. Date accessed: 5 August 2019.

Eberwein, Dieter. Nietzsches Schreibkugel: Ein Blick auf Nietzsches Schreibmaschinenzeit durch die Restauration der Schreibkugel. Schauenburg: Typoskript-Verlag, 2005. Part 1: < www.mallinghansen.org/fileadmin/schreibkugel/schreibkugel01.pdf>, Part 2: <www.malling-hansen. org/fileadmin/schreibkugel/schreibkugel02.pdf>. Date accessed: 17 November 2019.

Ervasti, Esko and Pertti Karkama. Suomen kirjallisuushistoria. Helsinki: Tammi, 1973.

Hawthorn, Jeremy. "'No need of words": Joseph Conrad's Use of the Typographical Ellipsis in Under Western Eyes and "The Secret Sharer"' Conradiana 43:2-3 (2011) 5-23. http://www.jstor.org/stable/24669416. Date accessed: 5 August 2019.

Helme, Heidi. Matka Jälkikuvasta Sudenkorentoon. Juha Mannerkorven trilogian eräitä rakenne- ja tyylipiirteitä. Yleisen kirjallisuuden sivulaudatur. Helsinki: Helsingin Yliopisto, 1995. 
Hulle, Dirk van. Modern Manuscripts: The Extended Mind and Creative Undoing from Darwin to Beckett and Beyond. London \& New York: Bloomsbury, 2014.

Hulle, Dirk van. 'Editing the Wake's Genesis: Digital Genetic Criticism.' In: Genevieve Sartor (ed.), James Joyce and Genetic Criticism: Genetic Fields. Leiden \& Boston: Brill \& Rodopi, 2018, 35-54.

Kinnunen, Aarne. 'Juha Mannerkorven Sudenkorennosta ja sen huumorista.' In: Ritva Haavikko (ed.), Rivien takaa: Nykykirjallisuuden tutkimusten kirjailijahaastattelujen pohjalta. Helsinki: Suomalaisen Kirjallisuuden Seura, 1976, 21-50.

Kinnunen, Aarne. 'Juha Mannerkorpi (1915-1980) and the metamorphosis of the self.' Books from Finland 2 (1982). http://www.booksfromfinland.fi/1982/06/juha-mannerkorpi-1915-1989-and-the-metamorphosis-of-the-self/. Date accessed: 5 August 2019.

Kittler, Friedrich. Discourse Networks 1800/1900. Trans. Michael Metteer and Chris Cullens. Stanford: Stanford University Press, 1990.

Kittler, Friedrich. Gramophone, Film, Typewriter. Trans. Geoffrey Winthorp-Young and Michael Wutz. Stanford: Stanford University Press, 1999.

Kokko, Mirja. 'Muistoista kuviksi: Surevan miehen mieli Juha Mannerkorven romaanissa Jälkikuva.' In: Liisa Ahlava and Pekka Tammi (eds.), Vaikeita fiktioita. Taideaineiden julkaisuja 12. Tampere: Tampereen yliopisto, 2009, 135-165.

Lankinen, Pasi. 'Juha Mannerkorpi-Modernin rajalla.' Bibliophilos 3 (2001) 36-40.

Lankinen, Pasi. 'Ilman sanoja: Juha Mannerkorven käsityksiä kielen merkityksestä.' In: Ilona Herlin, Jyrki Kalliokoski, Lari Kotilainen and Tiina Onikki-Rantajääskö (eds.), Äidinkielen merkitykset. Helsinki: Suomalaisen Kirjallisuuden Seura, 2002, 473-492.

Lejeune, Philippe. On Diary. Edited by Jeremy Popkin and Julie Rak. Trans. Katherine Durnin. Honolulu: University of Hawai'i Press, 2009.

Makkonen, Anna. 'Avaimia Juha Mannerkorven Avaimeen: Raamatusta, intertekstuaalisuudesta, tulkinnasta.' Kirjallisuudentutkijain Seuran vuosikirja 40 (1986a) 63-82.

Makkonen, Anna. 'Babel and Gethsemane: Biblical Myths in "The Key" by Juha Mannerkorpi.’ Scandinavian Studies 58:1 (1986b) 37-47.

Mannerkorpi, Juha. Avain. Helsinki: Otava, 1955.

Mannerkorpi, Juha. 'Beckettin “Millaista on”; mutinaa liejussa.' Uusi Suomi 332 (1962) 20.

Mannerkorpi, Juha. Jälkikuva. Helsinki: Otava, 1965.

Mannerkorpi, Juha. 'Beckettin ihmiskasvot.' Uusi Suomi 13.4.1966.

Mannerkorpi, Juha. Matkalippuja kaikkiin juniin. Helsinki: Otava, 1967.

Mannerkorpi, Juha. Sudenkorento: erään Pakaraisen esittävät seikkailut. Helsinki: Otava.

Mannerkorpi, Juha. 'Kolme vuosikymmentä sokeritautia.' In: Simo Talvitie (ed.), Aurinkoa pilvien lomasta. Helsinki: WSOY, 1972, 105-131.

Mannerkorpi, Juha. Päiväsinet. Muuan loppukesä, merkintöjä. Otava: Helsinki, 1979.

Mannerkorpi, Juha. 'About Calendars and Other Documents.' Books from Finland 2 (1982a). http://www.booksfromfinland.fi/1982/06/about-calendars-and-other-documents/. Date accessed: 8 August 2019.

Mannerkorpi, Juha. 'Muuan lähettämätön kirje kyselyyn eksistentialismista.' Parnasso 6 (1982b) 350-352.

Mikkola, Marja-Leena. 'Juha Mannerkorpi ja novelli.' In: Mirjam Polkunen and Auli Viikari (eds.), Suomalaisia kirjailijoita: kirjailijat kirjailijoista. Helsinki: Tammi, 1982, 297-306.

Mäkelä, Matti. 'Poikkeava ura.' Kirjojen meri. Professori Annamari Sarjaksen juhlakirja 12.10.1983. Helsinki: Suomalaisen Kirjallisuuden Seura, 1983, 125-130.

Nietzsche, Friedrich. Briefwechsel. Kritische Gesamtsausgabe. In: Giorgi Colli and Mazzino Montinari (eds.), Vol. 1 (3). Berlin, New York: Walter de Gruyter, 1981.

Poso, Eira. Aukeavalla spiraalilla: tutkimus Juha Mannerkorven teosten maailmankuvasta : erään kirjailija-persoonallisuuden fenomenologinen kuvaus. Helsinki: Suomalaisen Kirjallisuuden Seura, 1987. 
Riikonen, H. K. 'Juha Mannerkorpi.' Kansallisbiografia-verkkojulkaisu. Helsinki: Suomalaisen Kirjallisuuden Seura, 2005. http://urn.fi.libproxy.helsinki.fi/urn:nbn:fi:sks-kbg-004912. Date accessed: 5 August 2019.

Rodak, Pawel. 'Suffering and Writing: Autotherapeutic Functions of Some Polish Writers' Personal Diaries.' The European Journal of Life Writing 7 (2018) 161-169. https://doi. org/10.5463/ejlw.7.267. Date accessed: 5 August 2019.

Salin, Sari. 'Murheista muovailtu: Juha Mannerkorven melankolia.' Kirjallisuudentutkimuksen Seuran vuosikirja 51 (1998) 62-77.

Saviniemi, Kari. 'Eksistentialismia ja elämäntuntoa.' Kirjailija 3 (2015) 32-37.

Schilleman, Matthew. 'Typewriter Psyche: Henry James's Mechanical Mind.' Journal of Modern Literature 36:83 (2013) 14-30. https://www.jstor.org/stable/10.2979/jmodelite.36.3.14. Date accessed: 16 November 2019.

Raija Hurme, Riitta-Leena Malin and Olli Syväoja (eds.), Uusi Suomi-Englanti Suursanakirja. [1984]. Helsinki: WSOY, 1990.

\section{AUTHOR BIOGRAPHY}

Veijo Pulkkinen earned his PhD in literature at the University of Oulu in 2010. In 2018, he was awarded the Title of Docent at the University of Helsinki. From 2011 to 2014 Pulkkinen worked as a postdoctoral researcher funded by the Academy of Finland. He has published a monograph (Runoilija latomossa: geneettinen tutkimus Aaro Hellaakosken Jääpeilistä [2017, The poet in the typesetting room: A genetic study on Aaro Hellaakoski's Jääpeili]) and articles on visual poetry and the application of genetic and textual criticism to literary interpretation. In his current project, Pulkkinen studies the role of the typewriter in Finnish literature from genetic and medial perspectives.

\section{NOTES}

1 This work was supported by the Finnish Cultural Foundation (project number 00160791), the Alfred Kordelin Foundation (project number 170324) and the Ella and Georg Ehrnooth Foundation (project number 9769812).

2 For definitions of avant-texte, see for example, The Lexicon of Scholarly Editing: http:// uahost.uantwerpen.be/lse/index.php/lexicon/avant-texte/.

3 '13.50. Huh. Vihdoinkin tässä. Paloittelin ja ladoin ruukkuun broilerin kaikkine tykötarpeineen ja kiersin uunin lämpiämään. Jos tulee erityisen hyvää, hihhih, kirjoitan tähän reseptin, se on ihan omasta päästä.

Vihdoinkin tässä? Tuotako varten, lupausta varten tulevasta maanmainiosta broilerireseptistä? Piru tiesi. Mutta jollakin pohjaviritteisellä tavalla minulla on tälle paikalle kiire niin aamu kuin aamu. Tai paremminkin iltapäivä kuin iltapäivä, sillä aamunuokunnasta olen jo oppinut ettei sen väkivalytaista nujertanista kannata yrittää. Mutta tuo paine tähän, ja hienoinen veto samalla? Voisiko tuosta päätellä että tässä mitä nyt olen toista kuukautta kirjoittanut piilee jokin toteuttamisen arvoinen teema? Vanha mies, syöpätuomoin saanut, laskemassa päiviään. Ja iloitsemassa kun aina aukeaa uusi. Kun ukot ja mummot hoitelevat ikkunakukkasiaan, he arvattavasti hoitelevat oman jatkumisensa symboleja, pa.jon muun ohella, tietysti. 
Mutta eihän sitä tarvitse tietää jos siitä kirjoittaa esim. novellin. Jutun luulisi toimivan pelkästään sillä perusteella että kasvavan vaalimisessa ja katselemisessa on mukana ihmisen alkutarpeita. Paha vain että teema vaatii jonkinlaista naiiviutta, enkä minä ole semmoiseen ilmaisuun riittävän kokonainen.' (OD, 33) All translations from Finnish to English are by the author.

4 'Tekisi mieleni saada vihiä tätä ipomoeaa koskevasta kirjallisuudesta, semmoisesta joka kertoisi mahdollisista taioista, taoista, iskomuksista joita siihen liittyy. Sillä varmasti liittyy. Jos arvossa mäoisin ja rikkahitten rinnalla ja terveenä lisäksi, lähtisiin VäliAmerikkaan kyselemään sellaisia intiaaneilta. Vaan kun ei. Täytyy tyytyä kyselemään ylipuutarhureilta ja kasvitieteen professoreilta. Saanhan ainakin kasvitieteellistä tietoa hiukan enemmän kuin löytyy tietosanakirjasta. Eilen jo yritin, sain tietää seuraavaa: Alkuperäinen nimi Ipomoea, violadeae, sitten Linnén antama Ipomoea tricolor, ja vielä kolmas, Ipomoea rubrocoerulea mikä minusta on osuvin. Nimet ovat englanninkielisestä ja Turun yliopiston kasvitieteellisen puutarhan ylipuutarhurin Puupposen, hirveätä mikä määrä genetiivejä, suomentama KORISTEKASVIT, kuulemma värikuvateos vaikka kuva nimenomaan ipomoeasta huono. Lehtiä siinä tekstissä sanottiin herttamaisiksi, teräväkärkisiksi. Ei tämän meidän kotijumalan lehti minusta sovi herttamaisen lehtimuodon kalliksi.' (OD, 59-60)

5 'Lienee tehtövö taiat ja sepitettävä sadut itse.

Esimerkiksi näin:

Suuri Henki oli luonut taivaan ja maan ja kaiken siltä väliltä, vain tähdet puuttuivat, hän ei ollut niitä keksinyt vielä. Tapahtui sitten että hän muuanna yönä lähti Maahan karsomaan kättensä töitä ja katso, hyväthän ne olivat, mutta sattui olemaan kuuton aika ja vähän pimeätä. Niin Suuri Henki otti meren rannalta simpukan ja alkoi viiltää sen syrjällä taivaankalvoon reikiä. Suuri Henki viilsi niitä taivaankalvon täyteen, ja katso, nyt näkyivät vuorey ja kukkulat ja järvet ja ihmiset metsät ja metsänrannat tarkoin ja Suuri henki iloitsi vaeltaessaan töhtien valossa. Ja sitä mukaa kuin Suuri Henki oli leikannut taivaankalvoon reikiä, palaset olivat putoilleet maahan, ja kun aamu tuli niin katso,

suuria pyöreitä sinisiä taivaankalvon palasia oli puissa, pensaissa, kaikkialla kukkivat suuret siniset kukat.

Hm hmmm.' (OD, 85)

6 'Näinköhän tätä muuten on jatkettava tätäpäiväkirjan nimistä yhä? Tuntuu kuin alkaisi teeme tyhjetä. Kun heinäkuussa aloitin, tuntui kuin olisin tehnyt väkivaltaa jollekin mikä on, ruvennut siirtämään sitä kirjoitetun kielen maailmaan. Mutta tämä Päivänsinipä ei kalvennut millään tavoin. Sanatkalpenevat ja alkavat kyllästyttää, lopuksi loppuvat. Itse Sinen aistittavissa oleva todellisuus ei ele menettänyt mitään.

Ja siemeniä minulla on — niin moneksi vuodeksi kuin mitään muuta ei tapahdu. Tämä oli parempi kesä kuin aikoihin.

Ebkä minä tähän tätä sinikirjaakaan lopeta.' (OD, 90)

7 For a study of Mannerkorpi's Avain in English, see Makkonen 1986.

8 'Mikä hänet tekee ihmiseksi, hänet tekee ihmiseksi juuri tämä, että hänellä on tämä symbolifunktio/esittävä todellisuus kaikkinensa, kaikkine tietoineen jne. kaikki mikä sen piiriin kuuluu semmoista, joka esittää jotakin, joka sielullisella tapahtumana on fakta esim. unen näkeminen ja ajatteleminen, se on sielullisena tapahtumana tosiasia, mutta se esittää jotakin muuta mikä on ihan kokonaan muualla. Tämä juuri ihmisen ihmiseksi tekee ja niin kuin fraasi kuuluu "eroittaa hänet eläimestä".' (Tikkanen 1972, 322)

9 For an introduction and excerpts from Sudenkorento in English, see Kinnunen (1982) and Mannerkorpi (1982). 
10 Thus far, I have not been able to reliably identify the brand and model of the typewriter Mannerkorpi used at the time he wrote his diary. A picture published in an article by Kari Saviniemi $(1975,25)$ shows Mannerkorpi by his typewriter, which looks very much like a 1960s Erika model 10. I asked Aarne Kinnunen, who personally knew Mannerkorpi and visited him several times, about the typewriter. He did not have any idea about the model, but he was pretty sure that Mannerkorpi did not use an electric typewriter.

11 'Pumpulit korviin, pumpulit korviin. Heti kun kuulen kirjoituskoneen rämähtelevän näin kun nyt., tajuan pumpuleiden unohtuneen: on kuin kirjasimet nakuttaisivat suoraan rumpukalvoa.

Kas niin, pumpulit haettu. Napsahtelut kuuluvat tietysti nytkin mutta eivät tunnu kosketuksina.' (OD, 12-13)

12 'Pirut perkeleet saatanat jumalautat edessä: yritän caihtaa tähän esittävän todellisuuden tuottovälineeseen mustemman nauhan.

Kaksikymmentä minuuttia myöhemmin.

Muutamia yllämainiyyja avunhuutoja tarvittiin, hämmästyttävää kyllä.vain muutamia. Enkä ole aivan likomärkä. Piru olkoon, näkövammaisille pitäisi nauhanvaihtotarkoitukseen olla jokin kasettilaite, sitä automaarrisempi mitä vammaisemmasta kysymys.

Mutta aika mustaa tämäjälki näyttää olevan. Näen inturoillani kuten oli tarkoituskin: ei tarvitse joka tähystystä varten vaihtaa kantturoihin.' (OD, 11)

13 'Ja Sinisiä on tänä päivänä Viisi. Kirjoitan Sinisiä ja Viisi tahallani isolla kirjaimella, tämä erikseen mainittakoon koska kirjoitustekniikkani on mennyt kovin nykyaikaiseksi: alkaa epäilyttävästi muistuttaa tietokoneladontaa: virheitä virheitä virheitä, lyöntivirheitä, epätäydellisiä lauseita, käsittämättömiksi suistuneita sanoja. Niinkuin olisin yrittänyt kampurajalallani kävelylle.. Mikäs tähänkin tuli, yksi liikapiste lauseen loppuun. Kun jatkuvasti horjuu ja lipsuu teki mitä tahansa, jaa jaa, en muista mitä aioin sanoa.' (OD, 28)

14 'Kampurajalkaisen ehtoo-kävelyä... Mikäs tuohonkin tuli, kaksi liikapistettä lauseen loppuun, no, olkoot, kuvastelkoot mitä tahansa. Tulivat siihen kun yhden lyötyäni istuin käsi poskella puoli tuntia enkä tarkastanut joko olin lyönyt, sitten toisen puoli tuntia toinen käsi poskella ja katso, kun lopulta tarkastin, pisteitä oli kolme. Kun jatkuvasti h廿ourjuu ja lipsuu kaikessa yrittämässään, jaa jaa, en muista mitä aioin sanoa.' (RDT, 33)

15 'Hahhah, istuin tähän, näin eilisen merkinnän viimeisen sanan hm. Jos se nyt sana on. Mutta unen pohjaksi kelpaa. Selaan papereita,näitä päivänsiniliuskoja, niitä en paksu pinkka, selaan, pinkka yhä paksumpi ja minä totean: olen näköjään aivan liian usein sanonut "hm".' (RDT, 51-52) 